\title{
ATP-dependent and -independent Protein Degradation in Extracts of the Psychrotrophic Bacterium Arthrobacter sp. $\mathrm{S}_{1} 55$
}

\author{
By PATRICK POTIER, ${ }^{1 *}$ PASCAL DREVET, ${ }^{1}$ \\ ANNE-MONIQUE GOUNOT ${ }^{1}$ AND ALAN R. HIPKISS ${ }^{2}$ \\ ${ }^{1}$ Laboratoire de Microbiologie Physiologique et Appliquée, UA CNRS 697, Université Claude- \\ Bernard-Lyon 1, 43 boulevard du 11 Novembre 1918, 69622 Villeurbanne Cedex, France \\ ${ }^{2}$ Department of Biochemistry, King's College London, Strand, London WC2R $2 L S, U K$
}

(Received 13 March 1987; revised 27 May 1987)

\begin{abstract}
Proteolysis of endogenous and exogenous substrates in cell-free extracts of the psychrotrophic bacterium Arthrobacter sp. $\mathrm{S}_{1} 55$ has been compared. Endogenous proteins were degraded only after treatment with cyanogen bromide. The hydrolysis of exogenous proteins of high $M_{\mathrm{r}}$ (i.e. casein) was optimum at alkaline $\mathrm{pH}$ and was stimulated by $\mathrm{Ca}^{2+}, \mathrm{Mg}^{2+}, \mathrm{Mn}^{2+}$ and ATP. The serine protease inhibitor phenylmethylsulphonyl fluoride had no effect on ATP stimulation. Small peptides (i.e. insulin) were degraded at very high rates. This activity was optimum at slightly acidic $\mathrm{pH}$ and was stimulated by $\mathrm{Ca}^{2+}$, strongly inhibited by $\mathrm{Mn}^{2+}$, but not affected by ATP. Degradation of cyanogen bromide-treated cellular proteins displayed two $\mathrm{pH}$ optima which corresponded to the optimum $\mathrm{pH}$ for the degradation of insulin and casein. The characteristics of these acidic and alkaline activities were identical to those active against insulin and casein respectively. The proteases which degraded casein were much more heat resistant than those which degraded insulin.
\end{abstract}

\section{INTRODUCTION}

Until recently, intracellular protein degradation in micro-organisms has been mainly studied in 'standard' bacteria such as Escherichia coli or Bacillus megaterium. Under optimum growth conditions, the overall rates of protein breakdown within these cells are low (Calandruccio \& Larrabee, 1981; Chaloupka \& Strnadova, 1982; Willets, 1967), and most of the proteins synthesized during exponential growth are stable (Goldberg \& St John, 1976; Larrabee et al., 1980; Pine, 1972). However, changes in growth conditions can cause a rapid and selective degradation of certain enzymes (Rivett et al., 1985). Rapid rates of protein breakdown occur in various conditions such as starvation (Golberg \& St John, 1976; Mandelstam, 1960; Nath \& Koch, 1970; Pine, 1972), growth in the presence of agents that induce the production of abnormal proteins (Carr \& Woods, 1984; Goldberg \& Dice, 1974; Goldberg \& St John, 1976; Kemshead \& Hipkiss, 1974; Pine, 1972), or during a shift to high temperatures (Baker et al., 1984; Goff et al., 1984; Lindquist, 1986). It is now recognized that intracellular protein degradation is precisely regulated, and increased proteolysis appears to be an important physiological response of most organisms to adverse conditions.

In nature, many bacteria can grow harmoniously in very hostile environments such as polar regions and cold water, acidic hot springs, salterns, dry rock surfaces, deserts, or depths of the sea (Kushner, 1978). Such organisms are more able to withstand harsher conditions than typical mesophilic bacteria, e.g. E. coli, and they are often submitted to rapid variations of the environment. Several reports showed that the basal rate of protein turnover in micro-organisms that live in extreme environments, e.g. thermophiles (Amelunxen \& Murdock, 1978) and the

Abbreviations: PHMB, p-hydroxymercuribenzoate; PMSF, phenylmethylsulphonyl fluoride. 
moderate halophile Vibrio costicola (Hipkiss et al., 1980), is much greater than that in E. coli. It is therefore possible that rapid protein breakdown may provide these organisms with some selective advantage, and proteolysis could be an important regulatory system in the process of adaptation of the cells to unstable harsh conditions.

Psychrophilic bacteria must contend with temperatures close to freezing. Recent investigations showed that the rate of protein degradation in the facultative psychrophile (psychrotroph) Arthrobacter sp. $\mathrm{S}_{1} 55$ (which can grow between 0 and $32^{\circ} \mathrm{C}$ ) is high (Potier et al., 1985). As in other cells, this process is selective and it is stimulated when the cells are grown in the presence of miscoding antibiotics, or inhibited by inhibitors of ATP synthesis. An interesting observation was that the rate of proteolysis in Arthrobacter $\mathrm{S}_{1} 55$ is especially high at the maximum growth temperature (i.e. $32^{\circ} \mathrm{C}$ ). In vitro experiments revealed that there is considerably more protease activity in cells grown at $32{ }^{\circ} \mathrm{C}$ than in those grown at $10{ }^{\circ} \mathrm{C}$ (Potier et al., 1987). Furthermore, this activity differs qualitatively in cells grown at different temperatures. The physiological reasons for this modulation are still unknown. Thus, it is important to gain an understanding of the activity of the proteolytic apparatus, its specificity and its regulation. The experiments reported here were designed to investigate proteolytic activities in extracts of Arthrobacter sp. $\mathrm{S}_{1} 55$.

\section{METHODS}

Bacterial strain and growth conditions. Arthrobacter sp. S, 55 was grown at $20^{\circ} \mathrm{C}$ (optimum growth temperature) in a synthetic medium as previously described (Potier et al., 1985).

Chemicals. Reagents whose source is not mentioned were of the highest purity available, and were purchased from standard commercial sources. U-14 C-labelled L-amino acids [specific activity $60 \mathrm{mCi}(\mathrm{mmol} \mathrm{carbon})^{-1}$, $2.22 \mathrm{GBq}$ (mmol carbon) $\left.)^{-1}\right]$ were obtained from the Commissariat à l'Energie Atomique. $\left[{ }^{3} \mathrm{H}\right]$ Formaldehyde (specific activity $75 \mathrm{mCi} \mathrm{mmol}^{-1}$ ) was purchased from Du Pont de Nemours. Aqualyte scintillation cocktail was obtained from J. T. Baker. CNBr, EDTA, iodoacetamide and phenylmethylsulphonyl fluoride (PMSF) were from Merck. p-Hydroxymercuribenzoate (PHMB) was purchased from Fluka. Insulin, $\alpha$-casein, BSA, ATP (dipotassium salt), DTT, phosphocreatine (di-sodium salt) and creatine phosphokinase [160 units (mg protein) ${ }^{-1}$ ] were obtained from Sigma.

Preparation of cell-free extracts. Cells in exponential growth $(500 \mathrm{ml})$ were harvested by centrifugation at $12000 \mathrm{~g}$ for $10 \mathrm{~min}$ and the pellet was washed twice with fresh medium. Two methods for the preparation of cellfree extracts were used.

(i) Lysozyme treatment and sonication. The pelleted cells were resuspended in lysis buffer $[100 \mathrm{~mm}-\mathrm{Tris} / \mathrm{HCl}$

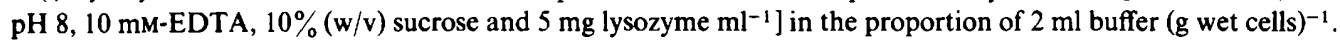
After $30 \mathrm{~min}$ incubation at $20^{\circ} \mathrm{C}$, cells were collected by centrifugation at $12000 \mathrm{~g}$ for $10 \mathrm{~min}$ and the pellet was resuspended in either buffer $\mathrm{C}$ ( $50 \mathrm{mM}-\mathrm{Tris} / \mathrm{HCl} \mathrm{pH} 8,10 \mathrm{~mm}-\mathrm{CaCl}_{2}, 10 \mathrm{mM}-\mathrm{MgCl}_{2}, 0.5 \mathrm{mM}-\mathrm{DTT}$ ), or in buffer I $\left(50 \mathrm{mM}\right.$-Tris/ $\mathrm{HCl} \mathrm{pH} 6.5,10 \mathrm{mM}-\mathrm{CaCl}_{2}, 0.5 \mathrm{~mm}$-DTT). Cell walls were then disrupted by sonication (Braun Labsonic, $50 \mathrm{~W}$ ) for six periods of $2 \mathrm{~min}$ with cooling in an ice bath. Unbroken cells were removed by centrifugation at $12000 \mathrm{~g}$ for $10 \mathrm{~min}$, and the supernatants were used immediately to examine protein breakdown.

(ii) Grinding with glass beads. The pelleted cells were resuspended in a small volume of either buffer C or I, and broken in a Braun-MKS grinder for $2 \mathrm{~min}$ at maximum speed with $0 \cdot 10-0 \cdot 11 \mathrm{~mm}$ diameter glass beads. Overheating was prevented by cooling with liquid $\mathrm{CO}_{2}$ for $10 \mathrm{~s}$ intervals every $20 \mathrm{~s}$. Unbroken cells and glass beads were removed by centrifugation at $12000 \mathrm{~g}$ for $10 \mathrm{~min}$, and the supernatant was used immediately to test protein degradation.

Preparation of radiolabelled substrates. Radiolabelled proteins of Arthrobacter $\mathrm{S}_{1} 55$ were obtained by adding a mixture of $\mathrm{U}^{-14} \mathrm{C}$-labelled amino acids (final concentration $0.025 \mu \mathrm{Ci} \mathrm{m}^{-1}$ ) to exponentially growing cells, and growth was continued for $15 \mathrm{~h}$. Cells were harvested by centrifugation at $12000 \mathrm{~g}$ for $10 \mathrm{~min}$. Labelled proteins were collected after mechanical disruption of the cells with glass beads as described above and stored at $-20^{\circ} \mathrm{C}$.

Insulin, BSA and casein were methylated with $\left[{ }^{3} \mathrm{H}\right]$ formaldehyde using the method of Rice \& Means (1970). The specific activity of the various preparations was approximately $2 \times 10^{6}$ c.p.m. (mg protein $)^{-1}$. The products were used immediately after preparation.

Chemical cleavage of Arthrobacter $S_{1} 55$ proteins. ${ }^{14} \mathrm{C}$-Labelled proteins of Arthrobacter $\mathrm{S}_{1} 55$ were cleaved by $\mathrm{CNBr}$ treatment according to the method of Kelley et al. (1973). The formic acid/CNBr solution was removed by lyophilization, the peptides dissolved in water, re-lyophilized, and the products stored at $-20^{\circ} \mathrm{C}$.

Determination of protein degradation. The degradation of $\left[{ }^{3} \mathrm{H}\right]$ casein was assayed in Arthrobacter $\mathrm{S}_{1} 55$ cell-free extracts prepared in buffer $\mathrm{C}$ (above) and that of $\left[{ }^{3} \mathrm{H}\right]$ insulin in buffer $\mathrm{I}$ (above). In vitro protein degradation was estimated by measuring the conversion of TCA-precipitable radioactivity into TCA-soluble radioactivity. 
Table 1. Rates of degradation of various substrates in cell-free extracts of Arthrobacter $S_{1} 55$ obtained after sonication of exponentially growing cells

Reaction mixtures $(200 \mu \mathrm{l})$ containing $100 \mu \mathrm{l}$ extract, $70 \mu \mathrm{l}$ buffer $(50 \mathrm{~mm}$-Tris $/ \mathrm{HCl} \mathrm{pH} 7 \cdot 6,50 \mathrm{mM}-\mathrm{KCl}$, $10 \mathrm{~mm}-\mathrm{MgCl}_{2}$ ) were incubated for $15 \mathrm{~min}$ at $20^{\circ} \mathrm{C}$ before the addition of the labelled substrates. Incubations were done at $20^{\circ} \mathrm{C}$ for $60 \mathrm{~min}$. The values represent the means $\pm S E$ of four independent experiments.

\begin{tabular}{|c|c|c|c|}
\hline Origin of substrate & Substrate & $\begin{array}{c}\text { Approximate } \\
M_{\mathrm{r}}\end{array}$ & $\begin{array}{c}\text { Hydrolytic activity } \\
{\left[\mathrm{h}^{-1}(\mathrm{mg} \text { protein in extract })^{-1}\right]}\end{array}$ \\
\hline $\begin{array}{l}\text { Endogenous } \\
\left.\text { (Arthrobacter } \mathrm{S}_{1} 55\right)\end{array}$ & $\begin{array}{l}{ }^{14} \mathrm{C} \text { - } \text { - } a b e l l e d \\
\text { total cellular } \\
\text { proteins }\end{array}$ & Mixture & $0.0 \pm 0.0$ \\
\hline & $\begin{array}{l}\text { CNBr-cleaved } \\
{ }^{14} \mathrm{C} \text {-labelled } \\
\text { cellular peptides }\end{array}$ & $\begin{array}{l}\text { Mixture of } \\
\text { short peptides }\end{array}$ & $28 \cdot 6 \pm 2 \cdot 8$ \\
\hline Exogenous & $\begin{array}{l}{\left[{ }^{3} \mathrm{H}\right] \mathrm{BSA}} \\
{\left[{ }^{3} \mathrm{H}\right] \text { Casein }} \\
{\left[{ }^{3} \mathrm{H}\right] \text { Insulin }}\end{array}$ & $\begin{array}{r}66000 \\
90000 \\
6000\end{array}$ & $\begin{array}{r}2 \cdot 5 \pm 0 \cdot 4 \\
5 \cdot 5 \pm 0 \cdot 9 \\
59 \cdot 0 \pm 5 \cdot 2\end{array}$ \\
\hline
\end{tabular}

Extracts $\left(100 \mu \mathrm{l}\right.$, containing $10-20 \mathrm{mg}$ protein $\left.\mathrm{ml}^{-1}\right)$ were mixed with $10 \mu \mathrm{l}$ radioactive substrates (approximately $10^{4}$ c.p.m.) and incubated at $20^{\circ} \mathrm{C}$. Samples $(50 \mu \mathrm{l})$ were removed at timed intervals, mixed with $5 \mu \mathrm{l} 5 \%(\mathrm{w} / \mathrm{v})$ BSA as a carrier and diluted into $50 \mu \mathrm{l}$ cold TCA $(10 \% \mathrm{w} / \mathrm{v})$. After $60 \mathrm{~min}$, the samples were centrifuged at maximum speed in an Eppendorf-type microfuge (MLW TH 21) for $2 \mathrm{~min}$. Samples $(50 \mu 1)$ of the supernatant were assayed for radioactivity in the presence of $2 \mathrm{ml}$ Aqualyte cocktail.

The optimum $\mathrm{pH}$ for proteolytic activity was determined in cell-free extracts obtained after sonication of the cells in $50 \mathrm{~mm}$-potassium acetate buffer $(\mathrm{pH} \mathrm{4-6.5)} \mathrm{or} \mathrm{in} 50 \mathrm{~mm}$-Tris/ $\mathrm{HCl}$ buffer $(\mathrm{pH} \mathrm{6-10)}$.

Protein determination. Protein concentration was determined by the Lowry procedure and calibrated using BSA as standard.

\section{RESULTS}

Determination of proteolytic activity in cell-free extracts of Arthrobacter $S_{1} 55$

Table 1 presents the rates of degradation of various substrates in cell-free extracts of Arthrobacter $\mathrm{S}_{1} 55$. When total ${ }^{14} \mathrm{C}$-labelled endogenous proteins were mixed with extracts obtained by sonication of the cells, no significant protein degradation was detected. The same result was observed with extracts obtained by mechanical grinding of the cells (data not shown). Several reports indicate that foreign proteins, abnormal molecules or small peptides are more sensitive in vivo and in vitro to proteolytic attack within various cells (Carrier et al., 1984; Etlinger \& Goldberg, 1977; George et al., 1980; Grinde \& Seglen, 1981; Kemshead \& Hipkiss, 1974, 1976). We therefore tested the ability of cell-free extracts of Arthrobacter $S_{1} 55$ to degrade ${ }^{14} \mathrm{C}$-labelled peptides obtained after $\mathrm{CNBr}$ cleavage of labelled endogenous proteins. High rates of protein degradation were observed with this type of substrate. In addition, the degradation of three exogenous proteins of differing $M_{\mathrm{r}}$ was compared. The smallest, insulin, was rapidly degraded whereas the larger proteins (i.e. BSA and casein) were degraded at much lower rates. The method of cell breakage (sonication or mechanical grinding) did not affect the rates of degradation of the various substrates tested. Since ultrasonic treatment seemed to have no effect on the activity of proteases under the conditions used, this method was preferred for practical reasons (e.g. more concentrated extracts).

\section{Effect of $p H$ on the degradation of casein and insulin}

To characterize the in vitro degradative system further, we examined the hydrolysis of proteins of various sizes as a function of $\mathrm{pH}:\left[{ }^{3} \mathrm{H}\right]$ casein, $\left[{ }^{3} \mathrm{H}\right]$ insulin and ${ }^{14} \mathrm{C}$-labelled $\mathrm{CNBr}$ peptides were tested over $\mathrm{pH}$ values ranging from 4 to 10 . Preliminary experiments showed that the release of TCA-soluble radioactivity from the substrates was linear for $20 \mathrm{~min}$ in the case of $\left[{ }^{3} \mathrm{H}\right]$ insulin, and for as long as $90 \mathrm{~min}$ in the case of $\left[{ }^{3} \mathrm{H}\right]$ casein (data not shown). Thus, the rate of degradation of insulin was determined after $10 \mathrm{~min}$ incubation periods, and that of $\left[{ }^{3} \mathrm{H}\right]$ casein 
Table 2. Effects of metal-chelating agents and ions on the degradation of $\left[{ }^{3} \mathrm{H}\right]$ insulin and $\left[{ }^{3} \mathrm{H}\right]$ casein in cell-free extracts of Arthrobacter $S_{1} 55$

Reaction mixtures $(200 \mu \mathrm{l})$, containing $100 \mu \mathrm{l}$ extract, $70 \mu \mathrm{l}$ of either buffer $\mathrm{I}(\mathrm{pH} \mathrm{6.5)}$ or $\mathrm{C}$ (pH 8 ), and the indicated inhibitors or ions, were incubated for $15 \mathrm{~min}$ at $20^{\circ} \mathrm{C}$ before the addition of the labelled substrates. When metal-chelating agents were tested, ions were omitted from both buffers. Incubations were done at $20^{\circ} \mathrm{C}$ for $10 \mathrm{~min}$ in the case of $\left[{ }^{3} \mathrm{H}\right]$ insulin, and for $60 \mathrm{~min}$ in the case of $\left[{ }^{3} \mathrm{H}\right]$ casein. Substrate hydrolysis in the absence of added inhibitors or ions is expressed as $100 \%$ activity, which for $\left[{ }^{3} \mathrm{H}\right]$ insulin and $\left[{ }^{3} \mathrm{H}\right]$ casein degradation was $3.0 \pm 0.8$ and $0.32 \pm 0.04 \mu \mathrm{g}$ hydrolysed $\mathrm{h}^{-1}$ (mg protein in extract $)^{-1}$ respectively. Means from five independent experiments are reported; the SE values were less than $10 \%$ of the recorded values.

$\begin{array}{cccc}\text { Addition } & \begin{array}{c}\text { Concn } \\ (\mathrm{mM})\end{array} & \overbrace{\left[{ }^{3} \mathrm{H}\right] \text { Insulin }}^{\text {Percentage degradation of }} & {\left[{ }^{3} \mathrm{H}\right] \text { Casein }} \\ \text { None } & - & 100 & 100 \\ \text { EDTA } & 5 & - & 98 \\ & 10 & 35 & 59 \\ o \text {-Phenanthroline } & 1 & - & 100 \\ & 5 & 25 & 82 \\ \mathrm{Mg}^{2+} & 5 & 104 & 161 \\ \mathrm{Ca}^{2+} & 5 & 145 & 270 \\ \mathrm{Mn}^{2+} & 5 & 44 & 165 \\ \mathrm{Co}^{2+} & 5 & 13 & 69 \\ \mathrm{Cu}^{2+} & 5 & 2 & 15 \\ \mathrm{Zn}^{2+} & 5 & 3 & 17\end{array}$

and ${ }^{14} \mathrm{C}$-labelled $\mathrm{CNBr}$ peptides after $60 \mathrm{~min}$. The degradation of $\left[{ }^{3} \mathrm{H}\right]$ casein was stimulated under alkaline conditions with a maximum rate at $\mathrm{pH} 8$, while degradation of $\left[{ }^{3} \mathrm{H}\right]$ insulin presented a narrow optimum at pH 6.5 (Fig. $1 a$ ). When total $\mathrm{CNBr}$-treated ${ }^{14} \mathrm{C}$-labelled proteins of Arthrobacter $\mathrm{S}_{1} 55$ were used as a substrate, both peaks were observed (Fig. $1 b$ ). This was probably due to the presence of a mixture of peptides of various sizes in the substrate. In the remaining experiments, therefore, the degradation of $\left[{ }^{3} \mathrm{H}\right]$ insulin was assayed at $\mathrm{pH} 6.5$, and that of $\left[{ }^{3} \mathrm{H}\right]$ casein at $\mathrm{pH} 8$, unless otherwise indicated.

\section{Metal ion requirement}

The degradation of $\left[{ }^{3} \mathrm{H}\right]$ insulin and $\left[{ }^{3} \mathrm{H}\right]$ casein in cell-free extracts of Arthrobacter $\mathrm{S}_{1} 55$ was strongly inhibited by $10 \mathrm{~mm}$-EDTA (Table 2). The hydrolysis of casein was only slightly affected by $5 \mathrm{~mm}-o$-phenanthroline (which chelates divalent cations more readily), whereas that of insulin decreased dramatically.

At $5 \mathrm{mM}$, both $\mathrm{Mg}^{2+}$ and $\mathrm{Ca}^{2+}$ stimulated the hydrolysis of $\left[{ }^{3} \mathrm{H}\right]$ insulin and $\left[{ }^{3} \mathrm{H}\right]$ casein in cellfree extracts of Arthrobacter $\mathrm{S}_{1} 55$. At the same concentration, $\mathrm{Co}^{2+}, \mathrm{Zn}^{2+}$ and $\mathrm{Cu}^{2+}$ inhibited the degradation of both molecules, whereas $\mathrm{Mn}^{2+}$ stimulated the degradation of $\left[{ }^{3} \mathrm{H}\right]$ casein, but had a strong inhibitory effect on the hydrolysis of $\left[{ }^{3} \mathrm{H}\right]$ insulin. The effects of $\mathrm{Ca}^{2+}, \mathrm{Mg}^{2+}$ and $\mathrm{Mn}^{2+}$ on the degradation of ${ }^{14} \mathrm{C}$-labelled $\mathrm{CNBr}$ peptides were also tested as a function of $\mathrm{pH}$. The addition of $\mathrm{Ca}^{2+}$ or $\mathrm{Mg}^{2+}$ to the extracts increased the rate of degradation of this substrate, but the profile observed in Fig. 1(b) was unchanged (data not shown). However, $\mathrm{Mn}^{2+}$ stimulated the degradation of $\mathrm{CNBr}$ peptides at alkaline $\mathrm{pH}$, but strongly inhibited the activity at acidic pH (Fig. 2).

\section{Sensitivity to protease inhibitors and effects of group specific reagents}

The effects of various protease inhibitors and group specific reagents on the degradation of $\left[{ }^{3} \mathrm{H}\right]$ casein and $\left[{ }^{3} \mathrm{H}\right]$ insulin in cell-free extracts of Arthrobacter $\mathrm{S}_{1} 55$ are shown in Table 3. 2-Iodoacetamide $(5 \mathrm{mM})$ inhibited the degradation of $\left[{ }^{3} \mathrm{H}\right] \mathrm{casein}$, and had no effect on the hydrolysis of $\left[{ }^{3} \mathrm{H}\right]$ insulin. The hydrolysis of both substrates was inhibited by $1 \mathrm{mM}-\mathrm{PHMB}$, which also reacts with thiol groups. Furthermore, the addition of $0.5 \mathrm{~mm}$-DTT to reaction buffers significantly increased the degradation of both substrates. The hydrolysis of both 


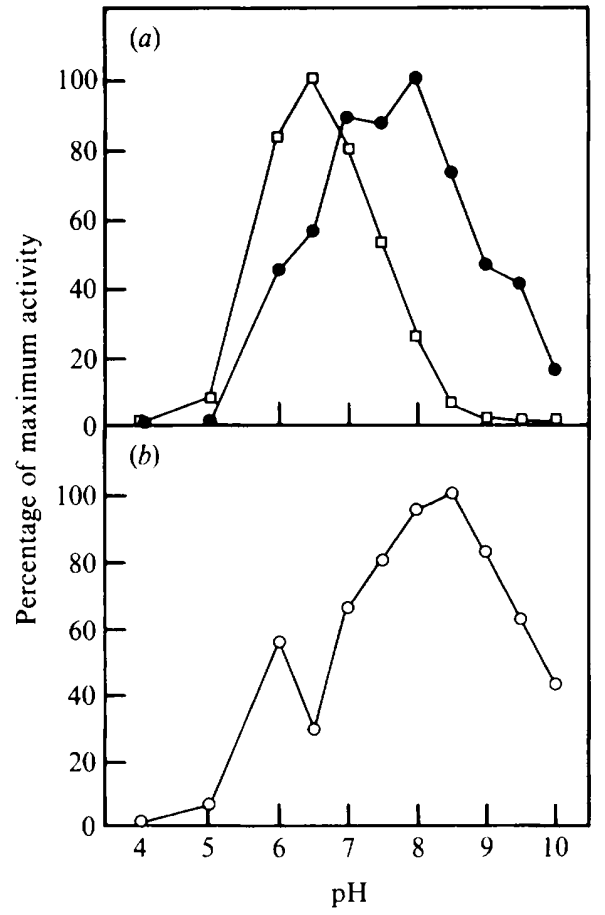

Fig. 1

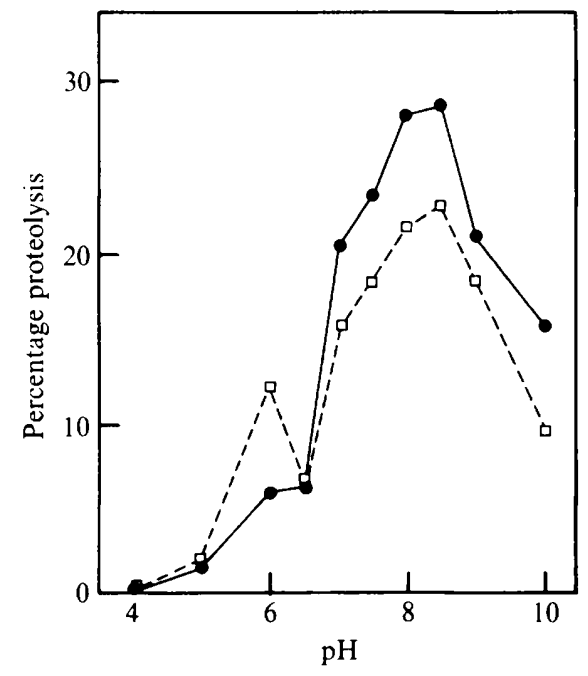

Fig. 2

Fig. 1. Effect of $\mathrm{pH}$ on the hydrolysis of $\left[{ }^{3} \mathrm{H}\right]$ casein, $\left[{ }^{3} \mathrm{H}\right]$ insulin and ${ }^{14} \mathrm{C}$-labelled $\mathrm{CNBr}$ peptides. (a) The degradation of $\left[{ }^{3} \mathrm{H}\right]$ casein $(\mathrm{O})$ and $\left[{ }^{3} \mathrm{H}\right]$ insulin $(\square)$ was assayed as described in Table 2, except that $50 \mathrm{~mm}$-potassium acetate buffer $(\mathrm{pH} 4-6.5)$ or $50 \mathrm{~mm}$-Tris/ $\mathrm{HCl}$ buffer $(\mathrm{pH} \mathrm{6-10)}$ were used instead of buffers $C$ and I. Maximum degradation of casein and insulin was $2 \cdot 8 \pm 0.6$ and $0.25 \pm 0.03 \mu \mathrm{g}$ hydrolysed $\mathrm{h}^{-1}$ (mg proteins in extract) $)^{-1}$ respectively. (b) Hydrolysis of the ${ }^{14} \mathrm{C}$-labelled $\mathrm{CNBr}$ peptides $(\mathrm{O})$ was assayed in the same conditions after $60 \mathrm{~min}$ incubation at $20^{\circ} \mathrm{C}$.

Fig. 2. Influence of $\mathrm{Mn}^{2+}$ on the degradation of ${ }^{14} \mathrm{C}$-labelled $\mathrm{CNBr}$ peptides in cell-free extracts of Arthrobacter $\mathrm{S}_{1} 55$ as a function of $\mathrm{pH}$. Reaction mixtures $(200 \mu \mathrm{l})$ contained $20 \mu \mathrm{l}$ extract, $140 \mu \mathrm{l}$ buffer at the appropriate $\mathrm{pH}$ with (O) or without ( $\square) 5 \mathrm{mM}-\mathrm{Mn}^{2+}$. Samples were incubated for 15 min at $20^{\circ} \mathrm{C}$ before the addition of the radioactive substrate, and the reaction was carried out for $60 \mathrm{~min}$ at the same temperature.

Table 3. Effects of protease inhibitors and group specific reagents on the degradation of $\left[{ }^{3} \mathrm{H}\right]$ insulin and $\left[{ }^{3} \mathrm{H}\right]$ casein in cell-free extracts of Arthrobacter $S_{1} 55$

Experiments were done as described in Table 2. Water-insoluble inhibitors were dissolved in ethanol before addition to the reaction mixtures; the control reaction mixture contained equal volumes of the solvent. The $100 \%$ activities for $\left[{ }^{3} \mathrm{H}\right]$ insulin and $\left[{ }^{3} \mathrm{H}\right]$ casein degradation were $3.3 \pm 0.8$ and $0.39 \pm 0.04 \mu \mathrm{g}$ hydrolysed $\mathrm{h}^{-1}$ (mg protein in extract) ${ }^{-1}$ respectively. The values represent the means \pm SE of four independent experiments.

None

PMSF

Iodoacetamide PHMB

DTT

-
1
5
10
5
1
$0 \cdot 5$

\section{Addition \\ Concn (mM)}

\section{Percentage degradation of}

$\begin{array}{cc}{\left[{ }^{3} \mathrm{H}\right] \text { Insulin }} & {\left[{ }^{3} \mathrm{H}\right] \text { Casein }} \\ 100 & 100 \\ 100 \pm 4 & 100 \pm 5 \\ 95 \pm 6 & 94 \pm 9 \\ 90 \pm 5 & 92 \pm 5 \\ 90 \pm 8 & 77 \pm 6 \\ 61 \pm 13 & 71 \pm 11 \\ 139 \pm 4 & 145 \pm 15\end{array}$




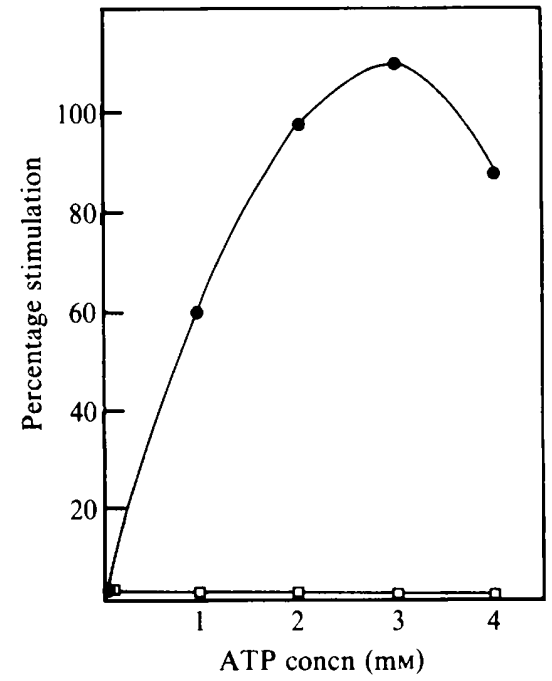

Fig. 3

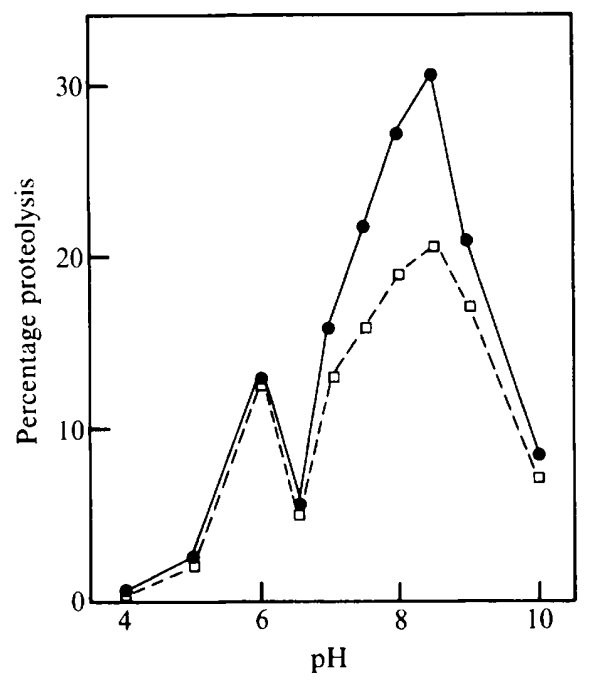

Fig. 4

Fig. 3. Effect of ATP on protein degradation in cell-free extracts of Arthrobacter $\mathrm{S}_{1} 55$. Experiments were done as described in Table 2. Extracts were incubated in the presence of ATP for $15 \mathrm{~min}$ at $20^{\circ} \mathrm{C}$ prior to the addition of labelled substrates: $\left[{ }^{3} \mathrm{H}\right]$ casein $(O)$ and $\left[{ }^{3} \mathrm{H}\right]$ insulin $(\square)$. Results are expressed as percentage stimulation of the proteolytic activity obtained in extracts incubated without ATP $\left[0.37 \pm 0.03 \mu \mathrm{g}\right.$ hydrolysed $\left.\mathrm{h}^{-1}(\mathrm{mg} \text { protein in extract })^{-1}\right]$.

Fig. 4. Effects of ATP on the degradation of ${ }^{14} \mathrm{C}$-labelled $\mathrm{CNBr}$ peptides as a function of $\mathrm{pH}$. Reaction mixtures $(200 \mu \mathrm{l})$ containing $20 \mu \mathrm{l}$ extract and $140 \mu \mathrm{l}$ buffer at the appropriate $\mathrm{pH}$ (see Methods) were pre-incubated for $15 \mathrm{~min}$ at $20^{\circ} \mathrm{C}$ in the presence (O) or absence ( $\square$ ) of an ATP-regenerating system before the addition of the labelled substrate. The ATP-regenerating system consisted of $3 \mathrm{mM}-\mathrm{ATP}$, $12.5 \mathrm{~mm}$-phosphocreatine and $0.02 \mathrm{mg}$ creatine phosphokinase $\mathrm{ml}^{-1}$. Incubations were done at $20^{\circ} \mathrm{C}$ for $60 \mathrm{~min}$.

$\left[{ }^{3} \mathrm{H}\right]$ casein and $\left[{ }^{3} \mathrm{H}\right]$ insulin was not affected by the serine protease inhibitor PMSF at the three concentrations tested.

\section{Effect of ATP on proteolytic activities}

The rate of degradation of $\left[{ }^{3} \mathrm{H}\right]$ insulin by cell-free extracts of Arthrobacter $\mathrm{S}_{1} 55$ was not affected by ATP at the concentrations tested (Fig. 3). However, incubation of the extracts with ATP markedly stimulated $\left[{ }^{3} \mathrm{H}\right]$ casein hydrolysis. The amount of stimulation increased with ATP concentration and was maximum at $3 \mathrm{mM}$. At this concentration, the rate of degradation of $\left[{ }^{3} \mathrm{H}\right]$ casein was twice that observed in extracts incubated without ATP. We also tested the effect of ATP on the degradation of ${ }^{14} \mathrm{C}$-labelled $\mathrm{CNBr}$ peptides as a function of $\mathrm{pH}$ (Fig. 4). ATP had no effect on the proteolytic activity observed in Fig. $1(b)$ at acidic $\mathrm{pH}$, but markedly stimulated the activity found under alkaline conditions. This stimulation was maximum at $\mathrm{pH} 8 \cdot 5$. The addition of increasing amounts of PMSF (up to $10 \mathrm{mM}$ ) to extracts of Arthrobacter $\mathrm{S}_{1} 55$ did not prevent the stimulatory effect of ATP on the degradation of $\left[{ }^{3} \mathrm{H}\right]$ casein.

\section{Heat inactivation of casein and insulin degradation}

The degradation of $\left[{ }^{3} \mathrm{H}\right]$ insulin and $\left[{ }^{3} \mathrm{H}\right]$ casein was assayed at $20^{\circ} \mathrm{C}$ after pre-incubating the extracts for $30 \mathrm{~min}$ at various temperatures (Fig. 5). Thermoinactivation of the hydrolysis of $\left[{ }^{3} \mathrm{H}\right]$ insulin occurred when the pre-incubation temperature was higher than $30^{\circ} \mathrm{C}$. The degradative system responsible for the degradation of $\left[{ }^{3} \mathrm{H}\right]$ casein was found to be more heat resistant since inactivation was achieved only above $50^{\circ} \mathrm{C}$. In fact, the activity increased dramatically after incubation at temperatures between 40 and $50^{\circ} \mathrm{C}$. This difference in the thermostability of the hydrolytic activity towards the two substrates tested strongly suggests the existence of distinct proteolytic systems in extracts of Arthrobacter $\mathrm{S}_{1} 55$. 


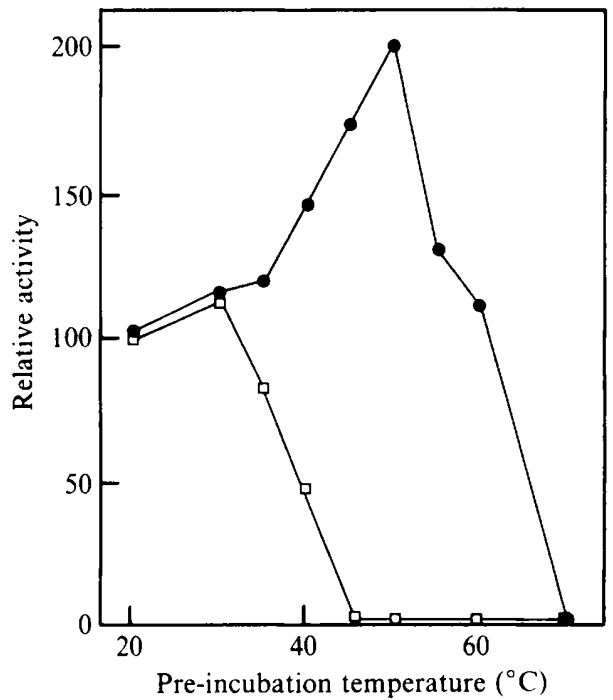

Fig. 5. Heat inactivation of protein degradation in cell-free extracts of Arthrobacter $\mathrm{S}_{1} 55$. Experiments were done at $20^{\circ} \mathrm{C}$ as described in Table 2, except that the extracts were pre-incubated at various temperatures for $30 \mathrm{~min}$ and allowed to cool before the addition of the labelled substrates: $\left[{ }^{3} \mathrm{H}\right]$ insulin $(\square)$ and $\left[{ }^{3} \mathrm{H}\right]$ casein $(O)$. Degradation of insulin and casein with untreated extracts was $4 \cdot 0 \pm 0.6$ and $0.37 \pm 0.03 \mu \mathrm{g}$ hydrolysed $\mathrm{h}^{-1}$ (mg protein in extract) ${ }^{-1}$ respectively.

\section{DISCUSSION}

The present experiments indicate that the efficiency of protein degradation in extracts of exponentially growing cells of Arthrobacter $\mathrm{S}_{1} 55$ depends upon the nature of the substrate: intracellular proteases seemed to have no or very little affinity for native proteins in vitro, unless this substrate was submitted to a chemical cleavage prior to enzymic attack. By exposing bacterial cells to radioactive amino acids for varying periods of time, Nath \& Koch (1970) revealed the existence of two general classes of proteins of different in vivo stability in bacteria: a small fraction that is degraded rapidly and another fraction that is more stable. The same observation has been made with Arthrobacter $\mathrm{S}_{1} 55$ (Potier et al., 1985). In the experiments reported here, the labelled native proteins were obtained by exposing the cells to radioactive amino acids for $15 \mathrm{~h}$. This would allow only the more stable fraction of the cellular proteins to be labelled, which could account for the lack of degradation of native proteins by cell-free extracts of Arthrobacter $\mathrm{S}_{1} 55$. However, appreciable proteolytic activity was detected in the extracts when $\mathrm{CNBr}$-treated proteins or exogenous peptides were used as substrates (Table 1). As observed in other cells (Carr \& Woods, 1984; Etlinger \& Goldberg, 1977), greater proteolysis of foreign proteins in the extracts correlated with the more rapid breakdown of abnormal proteins that has been described in exponentially growing Arthrobacter $S_{1} 55$ cells (Potier et al., 1985) and suggested that proteolysis in these preparations was related to breakdown in vivo. Therefore, it appears likely that endogenous proteins of Arthrobacter $\mathrm{S}_{1} 55$ were specifically protected in vivo and in vitro against attack by intracellular proteases. This would correlate with the general observation that proteins with abnormal structures, including shortened chain length, are rapidly and specifically degraded in Arthrobacter $S_{1} 55$ (Potier et al., 1985), and a wide range of exponentially growing cells (Carrier et al., 1984; Chaloupka \& Strnadova, 1982; Goldberg \& St John, 1976; Hipkiss et al., 1980; Kemshead \& Hipkiss, 1974; Pine, 1972), while the bulk of endogenous proteins remain stable.

We found that $\mathrm{CNBr}$ pre-treatment (which cleaves proteins at methionine residues) triggered the degradation of this normally stable substrate. This result compares with the observations of Kemshead \& Hipkiss (1976), who found that native alkaline phosphatase is stable in cell-free 
extracts of $E$. coli, whereas its CNBr products of low oligomeric $M_{\mathrm{r}}(<29000)$ are rapidly degraded to amino acids. In addition, we found that insulin (an exogenous protein of low $M_{\mathrm{r}}$ ) was degraded at very high rates by extracts of Arthrobacter $\mathrm{S}_{1} 55$, while larger molecules, i.e. BSA or casein, were more stable (Table 1). These variations in the rates of degradation of large and small proteins suggest that the degradative system in Arthrobacter $\mathrm{S}_{1} 55$ probably consists of several proteolytic enzymes whose activities depend, at least in part, on the size of the substrate.

In order to test the validity of this hypothesis, we examined the biochemical characteristics of the mechanisms involved in the degradation of exogenous proteins of different $M_{\mathrm{r}}$ (i.e. insulin and casein) by cell-free extracts of Arthrobacter $\mathrm{S}_{1} 55$. The data were compared to the degradation of $\mathrm{CNBr}$-treated endogenous proteins, which consist of a complex range of peptides of varying sizes. Our results indicate the existence of at least two distinct proteolytic systems. $(i)$ Maximal proteolytic activity was obtained under alkaline conditions with casein as substrate, and at pH 6.5 with insulin (Fig. 1). Furthermore, two peaks of activity were observed at these $\mathrm{pH}$ values when $\mathrm{CNBr}$ peptides were used as substrate. (ii) The degradation of these two substrates was inhibited to different extents by metal-chelating agents, thus indicating different ionic requirements for maximum activity. The rate of degradation of casein increased significantly when $\mathrm{Mg}^{2+}, \mathrm{Ca}^{2+}$ or $\mathrm{Mn}^{2+}$ was added to the reaction mixtures. The hydrolysis of insulin was stimulated only by $\mathrm{Ca}^{2+}$, and was strongly inhibited by $\mathrm{Mn}^{2+}$ (Table 2). The degradation of $\mathrm{CNBr}$ peptides was activated by $\mathrm{Mg}^{2+}$ and $\mathrm{Ca}^{2+}$ over the complete range of $\mathrm{pH}$, whereas $\mathrm{Mn}^{2+}$ inhibited the peak of activity observed at $\mathrm{pH} 6 \cdot 5$, and activated that at $\mathrm{pH} 8$ (Fig. 2). (iii) The degradation of both insulin and casein was activated by reducing conditions, but the proteolytic enzymes involved in the degradation of these two substrates presented different sensitivities to thiol group inhibitors (Table 3). (iv) ATP had no effect on the degradation of insulin, but stimulated that of casein up to twofold (Fig. 3). ATP stimulated the degradation of $\mathrm{CNBr}$ peptides only in alkaline conditions (Fig. 4). (v) The hydrolytic systems responsible for the degradation of insulin and casein were inactivated at different temperatures (Fig. 5). Casein hydrolysis was much more resistant to heat than was insulin degradation, thus indicating that at least one rate-limiting thermosensitive protease was involved in the degradative pathway of insulin, but not in that of casein.

Since the characteristics of the degradation of insulin and casein by cell-free extracts of Arthrobacter $\mathrm{S}_{1} 55$ were respectively identical to that of $\mathrm{CNBr}$ peptides at $\mathrm{pH} 6.5$ and 8 , it appears very likely that the differences observed for these two exogenous substrates were not due to some specific degradative reactions towards either molecule. Previous work (Potier et al., 1985 ) indicated that the initial endoproteolytic steps in protein breakdown in growing cells of Arthrobacter $\mathrm{S}_{1} 55$ require metabolic energy, and it is therefore likely that these steps are catalysed by the ATP-stimulated system responsible for the degradation of casein that we describe here. Because insulin is a small polypeptide, it may be degraded by enzymes involved only in the later steps in the complete degradation of cell proteins. Therefore, we suggest that intracellular protein degradation in Arthrobacter $\mathrm{S}_{1} 55$ could be a two-step mechanism. (i) An initial event of the proteolytic pathway may involve the specific recognition and partial cleavage of 'unprotected' molecules (e.g. altered endogenous proteins or exogenous peptides) by a class of proteases, one of them at least being stimulated by ATP. (ii) The shortened polypeptides released during this interaction may become the preferential substrate for a second set of proteolytic enzymes that would catalyse their rapid and complete degradation to amino acids. The nature of the discrimination between the two types of substrate could depend on substrate size, availability of terminal groups, exposure of internal amino acid residues, specific amino acid sequences, or any combination of these and other determinants of proteolytic susceptibility.

It is now well established that $E$. coli cells contain at least eight distinct soluble proteolytic enzymes, and their subcellular distribution has been determined (Goldberg et al., 1982; Swamy \& Goldberg, 1981, 1982). Two of them degrade insulin but not larger peptides, whereas the six others (including the ATP-dependent protease, protease La) degrade globin, casein and some peptides, but not insulin. Several observations indicate that an initial step in intracellular protein breakdown in these cells is catalysed by the ATP-stimulated protease La (Kowit \& Goldberg, 1977; Voellmy \& Goldberg, 1981). The characteristics of the proteolytic system 
responsible for the degradation of casein that we describe here resemble those reported for $E$. coli (Murakami et al., 1979) or rabbit reticulocytes (Etlinger \& Goldberg, 1977): optimum activity around $\mathrm{pH} 8$, stimulation by ATP, inhibition by EDTA, $o$-phenanthroline and iodoacetamide. However, the ATP-dependent activity observed in Arthrobacter $\mathrm{S}_{1} 55$ extracts was not affected by the serine protease inhibitor PMSF, as opposed to protease La in E. coli. It is therefore possible that the initial event of proteolysis in Arthrobacter $\mathrm{S}_{1} 55$ may involve at least one ATP-stimulated protease that is probably different from that found in $E$. coli. In order to gain an understanding of the intracellular signals involved in protein degradation, it should therefore be of interest to compare this enzyme(s) with protease $\mathrm{La}$, and we have already undertaken the purification of this enzyme(s). Another interesting development of this research would be the characterization in Arthrobacter $\mathrm{S}_{1} 55$ of the thermosensitive protease(s) involved in the degradation of small proteins. A primary task for further studies will be to determine whether similar proteases exist in other psychrotrophic micro-organisms, their physiological significance, regulation and role in adaptation of the cells to their environment.

This work was supported by grant CP 955010 from the Centre National de la Recherche Scientifique, France.

\section{REFERENCES}

AmelunXen, R. E. \& Murdock, A. L. (1978). Microbial life at high temperatures: mechanisms and molecular aspects. In Microbial Life in Extreme Environments, pp. 217-270. Edited by D. J. Kushner. New York: Academic Press.

Baker, T. A., Grossman, A. D. \& Gross, C. A. (1984). A gene regulating the heat shock response in Escherichia coli also affects proteolysis. Proceedings of the National Academy of Sciences of the United States of America 81, 6779-6783.

Calandruccio, J. H. \& Larrabee, A. R. (1981). Protein turnover in chemostat cultures of Escherichia coli. Archives of Biochemistry and Biophysics 210, 270274.

CARR, N. G. \& Woods, D. R. (1984). Protein degradation in extracts of exponential and stationary phase Vibrio cells. Journal of General Microbiology 130, 2775-2781.

Carrier, M. J., Kogut, M. \& Hipkiss, A. R. (1984). Changes in intracellular proteolysis in Escherichia coli during prolonged growth with a low concentration of dihydrostreptomycin. FEMS Microbiology Letters 22, 223-227.

Chaloupka, J. \& Strnadova, M. (1982). Kinetics of protein turnover in growing cells of Bacillus megaterium. Journal of General Microbiology 128, 1003-1008.

Etlinger, J. D. \& Goldberg, A. L. (1977). A soluble ATP-dependent proteolytic system responsible for the degradation of abnormal proteins in reticulocytes. Proceedings of the National Academy of Sciences of the United States of America 74, 54-58.

George, G. N., Worthington, V. C. \& Hipkiss, A. R. (1980). Inhibition of canavanyl-protein proteolysis in Escherichia coli by rifampin. Journal of Bacteriology 141, 1421-1423.

Goff, S. A., Casson, L. P. \& Goldberg, A. L. (1984). Heat-shock regulatory gene hipR influences rates of protein degradation and expression of the lon gene in Escherichia coli. Proceedings of the National Academy of Sciences of the United States of America 81, 66476651 .

Goldberg, A. L. \& Dice, J. F. (1974). Intracellular protein degradation in mammalian and bacterial cells (1). Annual Review' of Biochemistry 43, 835-869.
Goldberg, A. L. \& St John, A. C. (1976). Intracellular protein degradation in mammalian and bacterial cells (2). Annual Review of Biochemistry 45, 747-803.

Goldberg, A. L., Swamy, K. H. S., Chung, C. H. \& Larimore, F. (1982). Proteases in Escherichia coli. Methods in Enzymology 80, 680-702.

Grinde, B. \& SeGlen, P. O. (1981). Effects of amino acids and amino acid analogues on lysosomal protein degradation in isolated rat hepatocytes. Acta biologica et medica germanica 40, 1603-1612.

Hipkiss, A. R., Armstrong, D. W. \& Kushner, D. J. (1980). Protein turnover in a moderately halophilic bacterium. Canadian Journal of Microbiology 26, 196-203.

Kelley, P. M., NeumanN, P. A., Shriefer, K., Cancedda, F., Schlesinger, M. J. \& Bradshaw, R. A. (1973). Amino acid sequence of alkaline phosphatase. Amino- and carboxyl-terminal sequences and variations between two isozymes. Biochemistry 12, 3499-3503.

Kemshead, J. T. \& Hipkiss, A. R. (1974). Degradation of abnormal proteins in Escherichia coli: relative susceptibility of canavanyl proteins and puromycin peptides to proteolysis in vitro. European Journal of Biochemistry 45, 535-540.

KEMSHEAD, J. T. \& HIPKISS, A. R. (1976). Degradation of abnormal proteins in Escherichia coli: differential proteolysis in vitro of $E$. coli alkaline phosphatase cyanogen-bromide-cleavage products. European Journal of Biochemistry 71, 185-192.

KowIT, J. D. \& GoldBerG, A. L. (1977). Intermediate steps in the degradation of a specific abnormal protein in Escherichia coli. Journal of Biological Chemistry 252, 8350-8357.

KUSHNER, D. J. (1978). Introduction: a brief overview. In Microbial Life in Extreme Environments, pp. 1-7. Edited by D. J. Kushner. New York: Academic Press.

Larrabee, K. L., Phillips, J. O., Williams, G. J. \& LARRABEE, A. R. (1980). The relative rates of protein synthesis and degradation in a growing culture of Escherichia coli. Journal of Biological Chemistry 225, 4125-4130. 
LINDQUIST, S. (1986). The heat-shock response. Annual Review of Biochemistry 55, 1151-1191.

MaNdelstaM, J. (1960). The intracellular turnover of proteins and nucleic acids and its role in biochemical differentiation. Bacteriological Reviews 24, 289-308.

Murakami, K., Voellmy, R. \& Goldberg, A. L. (1979). Protein degradation is stimulated by ATP in extracts of Escherichia coli. Journal of Biological Chemistry 254, 8194-8200.

NATH, K. \& KOCH, A. L. (1970). Protein degradation in Escherichia coli. I. Measurement of rapidly and slowly decaying components. Journal of Biological Chemistry 245, 2889-2900.

NATH, K. \& KоСH, A. L. (1971). Protein degradation in Escherichia coli. II. Strain differences in the degradation of protein and nucleic acid resulting from starvation. Journal of Biological Chemistry 246, 69566967.

Pine, M. J. (1972). Turnover of intracellular proteins. Annual Review of Microbiology 26, 103-126.

Potier, P., Hipkiss, A. R. \& Kushner, D. J. (1985). Protein turnover in a psychrotrophic bacterium. Archives of Microbiology 142, 28-33.

Potier, P., Drevet, P., Gounot, A. M. \& Hipkiss, A. R. (1987). Proteolysis in cell-free extracts of the psychrophilic (cold-loving) bacterium Arthrobacter sp. $\mathrm{S}_{1} 55$. Biochemical Society Transactions (in the Press).
Rice, R. H. \& Means, G. E. (1970). Radioactive labelling of proteins in vitro. Journal of Biological Chemistry 246, 831-832.

Rivett, A. J., Roseman, J. E., Oliver, C. N., Levine, R. L. \& Stadtman, E. R. (1985). Covalent modification of proteins by mixed-function oxidation: recognition by intracellular proteases. In Intracellular Protein Catabolism, pp. 317-328. Edited by E. A. Khairalah, J. S. Bond \& J. W. C. Bird. New York: A. R. Liss.

Swamy, K. H. S. \& Goldberg, A. L. (1981). Escherichia coli contains eight soluble proteolytic activities, one of which is ATP-dependent. Nature, London 292, 652-654.

Swamy, K. H. S. \& Goldberg, A. L. (1982). Subcellular distribution of various proteases in Escherichia coli. Journal of Bacteriology 149, 10271033.

Voellmy, R. W. \& GoldberG, A. L. (1981). ATPstimulated endoprotease is associated with the cell membrane of Escherichia coli. Nature, London 290, 419-421.

WILLETS, N. S. (1967). Intracellular protein breakdown in growing cells of Escherichia coli. Biochemical Journal 103, 462-466. 